\title{
The Impact Of Education Existence Based On Pondok Pesantren In Drenges Village
}

\author{
Diah Puji Nali Brata, Maria Lusiana Nurohmasari \\ STKIP PGRI Jombang \\ pujidiah37@yahoo.com, marialusiana173021@gmail.com \\ Article History: $\quad$ Received: June 12 ${ }^{\text {th }} 2020$ \\ Revised: August $13^{\text {th }}, 2020$ \\ Accepted: September 30th, 2020
}

\begin{abstract}
Development is the most important aspect of community life in a country. The development of education is hampered by the way schools prioritize aspects of knowledge. Thus, boarding school-based education is needed as an educational institution that teaches knowledge, character, and skills. Some people still maintain the existence of Islamic boarding school-based education as the oldest educational institution in Indonesia. For this reason, the importance of discussing the topic of the existence of Islamic boarding school-based education is to provide knowledge about how Islamic boarding schools show their existence in the development of community education. The purpose of this study was to determine the supporting factors of Islamic boarding schools in developing community education and the impact of the existence of Islamic boarding school-based education on the development of education for the community in Drenges Village. The method used in this research is the qualitative method-research data obtained by interview, observation, and documentation. The results showed that the factors that support Islamic boarding schools in developing community education are the quality of teachers, the curriculum used, and learning activities. Meanwhile, the impact of boarding school-based education for the Drenges community is the increase in aspects of knowledge, skills, and the character of independence. The research results' importance is to provide a view to modern society that Islamic boarding school-based institutions can encourage the development of community education.
\end{abstract}

Keywords: Impact, Islamic boarding schools, educational development, education factors

\section{INTRODUCTION}

Education is an important aspect of community life. Education is a lesson that can be used to develop one's potential as an individual and society member. Education is a teaching that can be used to develop self-potential as individuals and members of society. Through education, people can develop aspects of knowledge, skills, and good attitudes as society members. These three aspects encourage people to master hard skills and soft skills that can be used in people's 
lives. However, in its implementation, several problems hinder the development of public education.

The problem in the development of education is that schools prioritize aspects of knowledge. These problems cause students to master knowledge but do not have good skills and character (Pangestuti et al., 2013: 4). People who do not have skills tend not to have soft skills in life. Apart from soft skills, people who are not taught character tend not to have morals. Thus, an educational institution is needed that has the function of developing knowledge and can develop skills and character. One of the educational institutions that can develop these three aspects of education is Islamic boarding schools.

The Islamic boarding school is an Islamic education institution based on the Islamic boarding school where the kyai are the teachers and the students are the learning students. The characteristic of education in Islamic boarding schools is that there is a tradition of teaching religious knowledge in its entirety. However, as educational institutions, pesantren also provide school or madrasah education as well as out-of-school education. School education aims to develop knowledge, while non-school education aims to develop soft skills for students. In addition to out-of-school education, adequate religious education is expected to shape the students' morals and personality. The existence of boarding school-based education is very important in the development of community education (Syafe'i, 2018: 94).

The existence of Islamic boarding school-based education is still maintained by the community in the modern era. As the oldest educational institution in Indonesia, Islamic boarding schools are still trusted by some people to learn. This belief has made Islamic boarding schools able to show their existence in the development of community education. The existence of Islamic boarding schools is indicated by the existence of a modern learning system while maintaining the tradition of teaching religion. (Anwar, 2016: 5). Based on this, the researchers analyzed research articles about the impact of the existence of boarding school-based education on the education of the Drenges village community.

The purpose of this study is to describe: (a) the supporting factors of Islamic boarding schools in developing community education, (b) the impact of the existence of Islamic boarding school-based education on the development of community education in Drenges Village. This research aims to provide knowledge about how Islamic boarding schools show their existence in the development of education and their impact on society in the modern era. 


\section{METHOD}

The type of research used in this study is qualitative research. According to Moleong (2011: 6), qualitative research is a comprehensive study of the phenomenon under study. This study aims to obtain data and seek meaning related to the phenomenon under study. By looking for meaning, researchers can find out the relationship between parts of the phenomenon about the impact of boarding school-based education on the development of education in the Drenges village community. These data are obtained through research subjects.

The research subjects in this study were alumni of the Mambaul Islamic boarding school, Hikmah Da'watul Khoir and the deputy principal of the Da'watul Khoir school in Drenges village, Nganjuk. The data taken from this subject is about the impact of Islamic boarding school-based education on the development of education in the Drenges village community. The research was conducted in AprilJune 2020. This study's data collection technique was through data triangulation, namely through interviews, observation, and documentation. The data obtained from this study will be analyzed to make research conclusions. Data analysis in this study was carried out according to qualitative research analysis techniques. According to Miles and Huberman (in Sugiyono, 2018: 246), the qualitative research data analysis activities are Data Reduction, Data Display (data presentation), and Conclusion Drawing / verification (conclusion and verification).

\section{RESULTS AND DISCUSSION}

\section{Factors That Support Pondok Pesantren In Developing Community Education}

\section{A. Quality of Teachers.}

Teachers are educational personnel who have an important role in the learning process. Teachers are responsible for guiding and teaching knowledge to students. In completing responsibilities, teachers must have teacher competence. Mastery of teacher competence is a determinant of the quality of teachers as educational personnel. For this reason, every educational institution must be able to support the improvement of teacher quality, including educational institutions based on Islamic boarding schools. One way that can be done to support the improvement of teacher quality is the socialization of educators and education personnel guidance. This activity serves to guide teachers and educators to be able to carry out their duties properly and be able to encourage the development of community education.

\section{B. Curriculum Used By Pondok Pesantren.}

The curriculum is an important component in achieving educational goals. The curriculum is a guideline, design, and direction for learning process activities, including Islamic boarding schools' learning process. During its development, 
Islamic boarding schools use a modern or classical education system which uses formal teaching methods and the curriculum used is a combination of the Ministry of Religion and the Education and Culture Office. The learning process carried out is learning in the classroom according to the education level of the students. The purpose of Islamic boarding schools using the modern education system and adapting the applicable curriculum is to provide education according to students' needs in the modern era.

\section{Learning Activities.}

Learning activities are learning activities designed by the teacher to achieve educational goals. In designing learning activities, teachers must pay attention to the aspects to be achieved. The attainment of the knowledge aspect can be done through learning activities in the classroom. However, the skills aspect's achievement requires learning activities in the form of practice outside the classroom. Learning activities carried out in Islamic boarding schools for the knowledge aspect are carried out in the classroom with certain teaching methods. To achieve the skills aspect, use activities outside the classroom such as practice in the laboratory, bringing in certain experts for socialization at school, and excursion studies to companies. The purpose of these activities outside the classroom is to provide learning experiences for students.

\section{Impact Of Education Existence Based On Pondok Pesantren In Drenges Village.}

\section{A. Knowledge Improvement.}

The knowledge aspect is an important aspect for the community to achieve. The result of the development of the knowledge aspect is that the community has extensive knowledge. Increasing this aspect of knowledge must be carried out properly by every educational institution. In Islamic boarding schools, the knowledge aspect is achieved by a formal learning process in the classroom. The curriculum used is a combination of the department of religion's curriculum and the curriculum of the department of education and culture. The use of the two curricula aims to ensure that students master academics and master religious knowledge.

\section{B. Skill Improvement.}

The skill aspect is an aspect that must be developed in society. Mastery of the skills aspect can produce soft skills that society needs. In Islamic boarding schools, the development of soft skills for students is carried out through the provision of vocational high schools (SMK). Through this school, students can hone their skills according to the chosen department. To improve their skills, every year students at the pesantren are sent to do industrial work practices. Skills 
development carried out by pesantren aims to provide experiences that can be used by students after graduating from the Islamic boarding school.

\section{Character Of Independence.}

Independence is a character that encourages someone to do something on their own, without help from others. This character of independence is one of the visions of the Islamic boarding school. To develop this character of independence, the pesantren accustom students to carry out individual activities on their own without the help of others. In addition to individual activities, pesantren also involve students in extracurricular activities such as scouts to increase their independence. In scout extracurricular activities, students are required to do routine exercises that must be carried out responsibly.

\section{DISCUSSION}

\section{Factors Supporting Pondok Pesantren In Developing Public Education.}

\section{A. Quality of Teachers.}

Teachers are educational personnel who have an important role in the learning process. Teachers are responsible for guiding and teaching knowledge to students. In completing responsibilities, teachers must have teacher competence. Mastery of teacher competence is a determinant of the quality of teachers as educational personnel. For that, every educational institution must be able to support the improvement of teacher quality. Based on the research results, the method used to support the improvement of the quality of Islamic boarding school teachers is the socialization of educators and educational staff. This activity serves to guide teachers and educators to be able to carry out their duties properly.

According to Dewi (2017: 2), improving quality is a way to improve community education development. The teacher is one of the learning components that play an important role in the learning process. Teachers must be able to make the learning process effective so that educational goals are achieved. To make effective learning, qualified teachers are needed. The existence of qualified teachers can encourage the development of community education. Improving teachers' quality can be realized in the form of activities to develop teachers and education personnel, such as those carried out by Islamic boarding schools. According to Suyono et al (2014: 19), teacher coaching aims to provide solutions for teachers as educators to create more effective learning. The teacher's success in creating effective learning, encouraging the achievement of learning objectives, and improving the quality of community education. 


\section{B. Curriculum Used By Pondok Pesantren.}

The curriculum is an important component in achieving educational goals. The curriculum is a guideline, design, and direction for learning process activities, including Islamic boarding schools' learning process. Based on the data obtained by researchers, Islamic boarding schools use a modern or classical education system which uses formal teaching methods and the curriculum used is a combination of the Ministry of Religion and the Education and Culture Office. This shows that Islamic boarding schools have adjusted to the predetermined curriculum. According to Prabowo (2018: 2), educational institutions need to adjust the applicable curriculum. Because the applicable curriculum is a curriculum that is under society's development and can overcome educational problems in society. The adjustment of educational institutions to the applicable curriculum results in learning according to the community's needs and can improve the quality of public education in the modern era.

\section{Learning Activities.}

Learning activities are learning activities designed by the teacher to achieve educational goals. In designing learning activities, teachers must pay attention to the aspects to be achieved. Based on the research results, learning activities carried out in Islamic boarding schools for the knowledge aspect are carried out in the classroom with certain teaching methods. To achieve the skills aspect, use activities outside the classroom such as practice in the laboratory, bringing in certain experts for socialization at school, and excursion studies to companies.

Learning activities carried out in Islamic boarding schools show that the pesantren has developed towards a modern direction. Pesantren is constructed into a formal school with learning activities inside and outside the classroom. According to Tolib (2015: 65), modern pesantren as formal schools aim to improve students' quality. With classroom learning activities and appropriate teaching methods, students can master science and technology. In addition to classroom learning, learning activities in modern Islamic boarding schools can be carried out outside the classroom. Activities outside the classroom can be done in the form of practice to improve skills. According to Sugiantari (2016: 11), learning activities outside the classroom can provide experiences for students. This experience is learning that can develop the skills of students. The existence of skills development can improve the soft skills of students needed in social life. 


\section{Impact Of Education Existence Based On Pondok Pesantren In Drenges Village.}

\section{A. Knowledge Improvement.}

The knowledge aspect is an important aspect for the community to achieve. Increasing this aspect of knowledge must be carried out properly by every educational institution. In Islamic boarding schools, the knowledge aspect is achieved by a formal learning process. To carry out formal learning, Islamic boarding schools adjust the applicable curriculum. The curriculum used is a combination of the department of religion's curriculum and the curriculum of the department of education and culture. According to Tolib (2015: 65), the formal learning system in Islamic boarding schools is following society's needs in the modern era. By adjusting the applicable curriculum, students can master the knowledge and be able to adapt to the times.

\section{B. Skill Improvement.}

The skill aspect is an aspect that must be developed in society. In Islamic boarding schools, the skills development of students is carried out through the provision of vocational high schools (SMK). Through industrial work practice activities at SMK, it is hoped that it can improve the students' skills aspects. According to Rozi (Syahroni, 2014: 3), industrial practical work activities have benefits, among others, (1) encouraging skills improvement, (2) being able to apply the theory learned, (3) gaining professional experience and expertise. So that the procurement of these vocational high schools is very appropriate because it can improve skills. Santri apart from acquiring skills can prepare professional skills according to their desired job.

\section{Character Of Independence.}

Independence is a character that encourages someone to be able to do something on their own, without help from others. To develop this character of independence, the pesantren accustom students to carry out individual activities independently without the help of others. According to Sa'diyah (2017: 32), the character of independence can be instilled through habituation to carry out activities and solve problems on their own. Through this habit, a person learns to deal with situations and is able to solve problems independently. Apart from habituation, independence can be obtained through joint activities in which individuals have certain responsibilities.

The activity used to foster the character of students' independence in Islamic boarding schools is scout extracurricular activities. In scout extracurricular activities, students are required to follow routine exercises with full responsibility. According to Larasati (2017: 2), one of the efforts to instill a character of independence is to involve students in scout extracurricular activities. Through 
activities such as routine exercises, students are responsible for completing individual tasks independently. In completing assignments, students will learn to overcome difficulties faced without the help of others.

\section{CONCLUSION}

Islamic boarding schools are experiencing development from a traditional education system to a modern education system. The purpose of pesantren to develop a modern education system is to encourage the development of public education. To achieve this goal, pesantren strives to improve teacher quality through training and socialization activities, curriculum adjustments, and designing effective learning activities. The existence of these efforts can support the development of community education.

The modern education system in pesantren has a positive impact on the development of public education. Islamic boarding schools develop formal learning that can improve aspects of community knowledge and skills. Improved aspects of knowledge and skills obtained through classroom activities and practice outside the classroom. Another positive impact is an increase in the character of independence obtained through individual activities and extracurricular activities. Suggestions that can be given are as follows:

a. For Islamic boarding schools.

To the pesantren, to maintain the modern education system in order to maintain the existence of the Islamic boarding school.

b. For the Community.

To the community to support Islamic boarding schools' efforts in increasing their existence for the development of education.

c. For students or students.

The efforts of Islamic boarding schools to develop a modern education system have had a positive impact. To get this positive impact, students must follow the learning activities at the Islamic boarding school properly.

\section{REFERENCES}

Pangaestuti,Rini,dkk. (2013), Faktor-Faktor Penyebab Guru Dalam Mengimplementasikan Pembelajaran Beranah Afektif di SMP Negeri 4 Sekampung Lampung Timur, http://media.neliti.com/media/publications/249637-none-1851870b.pdf, diakses 3 Mei 2020.

Syafe'i,Imam.(2018),Pondok Pesantren, Lembaga Pendidikan Pembentuk Karakter,http://media.neliti.com/media/publications/177493-ID-pondokpesantren-lembaga-pendidikan-pemb.pdf, diakses 3 Mei 2020

Anwar.(2016).Karakteristik Pendidikan Dan Unsur-Unsur Kelembagaan Di Pesantren, http://ejournal.uin- 
suska.ac.id/index.ph[/potensia/article/download/2536/1605.pdf, diakses 3 Mei 2020

Sugiyono (2018). Metode Penelitian Kuantitatif Kualitatif, Dan R\&-d.Bandung : ALFABETA CV.

Dewi,Ni wayan Erna purna.(2017).Meningkatkan Kualitas Guru Yang Lebih Baik,http://www.researchgate.net/publication/31509931 MENINGKATKA N KUALITAS GURU UNTUK PENDIDIKAN YANG LEBIH BAIK.pdf , diakses 10 juni 2020

Suyono dan Hariyanto.(2014). Belajar Dan Pembelajaran. Bandung: Remaja Rosdakarya.

Prabowo,Hari.(2018). Pentingnya Peranan Kurikulum Yang Sesuai Dalam Pendidikan,http://osf.io/vu3tx/download/\%3Fformat\%3Dpdf,diakses 10 juni 2020

Tolib,Abdul.(2015).Pendidikan di Pondok pesantren Modern, http://jurnal.falunwir.ac.id, diakses 22 juni 2020.

Sugiantari, putu ema.(2016).Pembelajaran Diluar Kelas Sebagai Upaya Sebagai Peningkatan Dan Optimalisasi Daya Serap Siswa,http://simposium.gtk.kemendikbud.go.id, diakses 22 juni 2020.

Syahroni,Fitria.(2014).Persepsi Siswa Terhadap Manfaat Pelaksanaan Praktek Kerja Industri Di SMKN 1 Lembah Gumanti, http://ejournal.unp.ac.id/index.php/bahana/article/viewFile/3762/2996. pdf, diakses 22 juni 2020.

Sa'diyah.R.(2017).Pentingnya Melatih Kemandirian Anak, http://journal.uinjkt.ac.id/index.php/kordinat/article/download/6453/39 49.pdf, diakses 23 juni 2020.

Larasati.(2017).Pendidikan Karakter Mandiri Melalui Kegiatan Ekstrakurikuler Pramuka di Sekolah Dasar, http://eprints.uny.ac.id/46532.pdf, diakses 23 juni 2020. 